\title{
Campaign Contributions and Judicial Behavior
}

\author{
Damon M. Cann
}

Many states select judges using competitive elections. Proponents of appointment plans contend that judicial candidates may be tempted to grant favors to lawyers who donate to their campaigns, thus compromising the independence of the judiciary. I contend that previous studies have failed to rigorously test the hypothesis that campaign contributions directly affect judicial decision-making. Using data from the 1998 term of the Wisconsin Supreme Court, I show that lawyers who make campaign contributions are no more likely to win cases than lawyers who do not. Furthermore, the data show that judges who are faced by lawyers who contributed large amounts to their campaigns are more likely to recuse themselves.

\section{Introduction}

Much has been made of a potential link between judges decisionmaking and campaign contributions from interested parties. Such a connection, of course, would be grounds for great concern - if judges could indeed be "bought," the implications for justice would be profound. Individuals within and without the legal profession have voiced particular concern about contributions from attorneys to the judges before whom they argue.

Concerns about corruption in judicial elections fall within a vast literature on judicial selection. The paradox of judicial selection is that election plans maximize accountability at the cost of independence, and appointment plans maximize independence at the cost of accountability to the citizenry. Between the two ends of the judicial selection spectrum stand two popular compromise plans. Non-partisan elections move toward the middle from partisan elections. In non-partisan elections, judicial candidates are not allowed to identify with or be members of a political party. A second strategy, the Missouri Plan, moves toward the middle from the appointment side. Under the Missouri Plan, appointed judges must stand for a retention election after holding office for a brief period of time.

Both partisan and non-partisan elections are criticized for similar reasons. First, reform advocates claim that elections do not actually promote accountability because the electorate is not well-informed (Dunn 1976). However, Hall (2001) provides evidence to refute this contention. In

DAMON M. CANN is a Ph.D. student in the Department of Political Science, State University of New York, Stony Brook. The author thanks Samantha Sanchez and the National Institute for Money in State Politics for providing data for this article, and he thanks Jeff Segal and Mark Berger for their helpful comments.

The American Review of Politics, Vol. 23, Fall, 2002: 261-274

(C)2002 The American Review of Politics 
a national study of elections to state supreme courts, Hall showed that factors such as candidate ideology and the state's murder rate (a key issue) influence the outcomes of partisan and nonpartisan elections. This evidence of judicial accountability led Hall to conclude that candidate attributes and issues affect the outcome of judicial elections. Hall (1992) further shows that state supreme court justices believe that issues matter to voters-enough so to strategically change their decisions on salient cases.

A second criticism leveled at competitive election selection plans is that elections diminish the independence of the judiciary. One way in which independence could be compromised is through the influence of partisan pressures. Hall (2001) shows that partisan pressures do influence judicial elections, but she contends that the Missouri Plan also fails to isolate judges from party pressures. She demonstrates that party competition and the party of the challenger (or the party of the governor who would make a new appointment in a retention election) influence the outcome of the election. If appointments to the Supreme Court are any indication, even appointment processes would be influenced by partisan politics as long as a political officer or body affected the appointment (consider Segal and Spaeth 1993). Thus, while judicial elections allow partisan influences on justices, their alternatives do not seem to be any better.

Another way in which elections could compromise judicial independence is through the influence of campaign contributions. Judges may be tempted to use the power of their office to raise funds to pursue their own reelection. To this end, the American Bar Association (ABA) encourages states to establish conditions under which judges should recuse themselves when faced by a campaign donor.

The American Bar Association's 1924 Model Canons of Judicial Ethics states, "A judge should not accept any presents or favors from litigants, or from lawyers practicing before him or from others whose interests are likely to be submitted to him for judgment" (ABA 1924, 225). However, this language was superceded by changes in ABA policy. Amendments in 1972 and again in 1990 allowed judicial candidates to accept contributions through a campaign committee, within certain limits (ABA 1990, Canon 5). The most recent changes to the Model Code suggest that judges should recuse themselves when hearing cases involving a party or attorney who has contributed more than an amount to be chosen by the state (ABA 1999, Canon 5; ABA policy changes reviewed by California Commission on Campaign Financing 1995, 79-81).

However, the model codes are not binding on attorneys - they must first be adopted by the states which may alter the original model code. In Wisconsin, for example, there is no set level at which a judge must recuse himself/herself; however, the judges may not personally solicit campaign 
funds (this must be done by a campaign committee-Wisconsin Court System Rules 2002, 60.06).

The American Bar Association's Standing Committee on Judicial Independence (2001) has reconsidered the potential consequences of private parties donating to judicial campaigns. The Committee fears that escalating campaign costs may lead judges to compromise their integrity to raise enough money to wage a successful campaign. They have considered full public funding of judicial campaigns as a solution. However, before jumping to a policy conclusion, one must establish that campaign contributions do threaten the integrity of the court system.

Two avenues exist for the influence of money. First, contributions may affect the composition of courts; candidates who are well-funded will dominate candidates who are not (e.g., Champagne 1986, 90-92; Jackson and Riddlesperger 1991). Second, candidates who receive contributions may feel compelled to reciprocate by voting in accordance with their donors' wishes (quid pro quo). While both avenues of influence have been well-explored in congressional elections (e.g., Grenzke 1989; Wright 1996) and state legislative elections (Thompson and Moncrief 1998), fewer scholars have considered judicial elections. This article investigates the possibility of quid pro quo behavior between judges and donors.

Prior work in this area overwhelmingly has suggested that improper influence abounds in the judiciary. However, shortcomings in the analyses make additional study desirable. Existing research can be grouped into three categories based on their research strategies. The first group in this body of research merely contents itself with showing that campaign donors sometimes appear in the courtroom. In this class we find a multitude of works (Pallasch 2001; Hansen 1991; Dubois 1986) that simply point out that judges receive contributions from lawyers, and they claim that is wrong of itself. Observing the existence of these situations, however, is only meaningful if one can determine that anything improper actually occurs.

The second group of research tries to demonstrate a correlation between campaign contributions and a judge's decisions, but most of these works marshal their evidence from anecdotes. For example, Champagne $(1986 ; 1988)$ contends that the pool of potential donors for judicial elections is so small that candidates are forced to solicit donations from lawyers and potential litigants to finance increasingly expensive campaigns. In Texas, both winners and losers raise a large share of their funds from a small number of donors. In the mid-1980s, two Texas Supreme Court justices were admonished or reprimanded for accepting large donations from lawyers who had interests pending in that court (Champagne 1988, 149).

Schotland (1985) follows a similar research design, but he draws anecdotes from states beyond Texas. The costs of judicial campaigns were shown 
to be high even in the early 1980s, using figures from Alabama, California, Florida, New York, Pennsylvania, Texas, and Wisconsin. He then presents several incidents of purported impropriety involving donations between judicial candidates and lawyers.

Banner (1988) presents an anecdote from the Texas Court of Appeals, 4th District. Several appellants faced an attorney who had contributed to the campaigns of two of the three judges on the panel. The result was a 3-0 decision against the appellants. Banner offers this as evidence that the judge's votes were bought, but he offers no explanation for the vote of the third judge who did not receive contributions. Still, a more fundamental problem with using anecdotal evidence is the temptation to generalize the most drastic cases to reality. Selecting cases based on their outcome cannot yield a reliable estimate of the general correlation between contributions and decisions. A more sound approach would consider all cases appearing before a court or multiple courts.

Ware (1999) comes closer to that ideal by examining arbitration decisions from the Alabama Supreme Court, and he finds a correlation between the source of a judge's funding and the judge's votes. However, Ware (1999, 661) admits in the article that this correlation cannot determine causality. It could be that individuals give to judges who are already ideologically aligned with them, and the judges simply vote along ideological lines. Furthermore, the presence of predictable divisions in a court cannot be explained by contributions because predictable divisions can also be found in courts with appointed judges.

The third group of research trying to show the influence of money on judicial decisions bases its case on opinion polls. A survey of Texas judges, court personnel, and attorneys asked respondents whether the influence of campaign contributions was "very significant," "fairly significant," "not very significant," or of "no" influence. Forty-eight percent of judges indicated that contributions had a "very" or "fairly" significant effect, while about two-thirds of court personnel responded in those same two categories. Thirty-seven percent and forty-two percent of attorneys felt that contributions had "very" or "fairly" significant effects, respectively (Supreme Court of Texas et al. 1999).

A national survey asked individuals to indicate their level of agreement with the statement, "Elected judges are influenced by having to raise campaign funds." Seventy-eight percent of respondents either "strongly" or "somewhat" agreed (National Center for State Courts, 1999). These findings echo the sentiments of respondents to an earlier survey of Texas lawyers (Jackson and Riddlesperger 1991).

While the opinions of both elites and non-elites are interesting, it is preferable to directly examine the decisions of the judges. The actual 
relationship between contributions and judicial decisions ought to be an empirical question rather than a matter of recall, or one person's opinion of another person's decision.

The most direct and accurate way to assess the relationship between campaign contributions and judicial decisions is to compare the outcomes of cases with the contributions made by interested parties. It actually is quite rare for the parties involved in a case to have been contributors to judicial campaigns. Individuals have little incentive to contribute because there is only a minimal probability they will appear in court. However, since attorneys appear in court more frequently, it is not uncommon for an attorney to argue a case before a judge to whom he or she has contributed. The natural question to ask, then, is whether judges behave differently when faced by attorneys who contributed to their campaign. Specifically, I will examine judge's votes and recusal before attorneys who contributed to their campaigns.

\section{Case Study: The Wisconsin State Supreme Court}

To understand the relationship between attorney campaign contributions and case outcomes, I examine cases decided in 1998 by the Wisconsin Supreme Court, the Wisconsin court of last resort. The court consists of seven justices who are elected to 10-year terms of office. Elections are staggered so that only one justice is replaced each year. Incumbents are elected at a very high rate. In fact, no incumbent has lost in the last 10 years, the only turnover of justices coming from retirements. Even then, the election is often won by the individual appointed by the governor to fill the remainder of the departing justice's term. Although the justices rarely face a very competitive election, they must still raise significant amounts of money.

While the judicial elections in Wisconsin are non-partisan, five of the previously were identified as Republicans (Steinmetz, Wilcox, Crooks, Bradley, and Geske), and two as Democrats (Chief Justice Abrahamson and Bablitch). As such, the court (for that term) shows conservative leanings.

The Wisconsin Supreme Court exercises control over its own docket. Cases are selected on appeal from Courts of Appeals by direct review (where the court chooses a case before it is heard in the Court of Appeals), on a bypass petition (where a party to the case asks to skip over the Court of Appeals, or in a few cases, by original jurisdiction (especially disciplinary cases for attorneys). The court hears about 100 cases each year. On case selection, the court's internal operating procedures state:

When a matter is brought to the Supreme Court for review, the court's principal criterion in granting or denying review is not whether the matter was correctly decided or justice done in the lower court, but whether the 
matter is one which should trigger the institutional responsibilities of the Supreme Court. The same determination governs the exercise of the court's original jurisdiction (Wisconsin Supreme Court, 1984).

Wisconsin's 1998 term makes an ideal case study for several reasons. First, the judges sitting during that term all had faced an election (none of the sitting justices were appointees who had not yet faced an election battle). Second, in Wisconsin, individuals may distribute up to $\$ 10,000$ to any combination of state-wide candidates (FEC 2001). Third, the court hears many cases where attorneys have contributed varying amounts of money. Finally, data on the decisions and contributions are already available from the National Institute on Money in State Politics (NIMSP) which has a database of contributions to judicial campaigns in Wisconsin. The remaining task was to match the contribution records of the attorneys who argued the case with the case outcomes.

\section{Lawyer Contributions and Courtroom Success: Case-Level Outcomes}

First, I present descriptive statistics on contributions and case outcomes. The average contribution for donors who reported their occupation as "Attorney" or "Lawyer" was $\$ 150$, but the maximum was $\$ 10,000$. The largest contributor who appeared before the court in 1998 gave $\$ 2,025$.

Tables 1 and 2 show the success rates of attorneys who contributed to a judge's campaign versus the success rate of attorneys who did not contribute. In Table 1, we see that when the plaintiff's attorney did not contribute, plaintiffs won more cases than they lost. When plaintiff's attorneys did contribute, they lost more cases than they won. This outcome is precisely the opposite of the pattern one would expect if there were a connection between campaign contributions and judge's votes. Fisher's exact test shows that these results are not statistically significant. Table 2 shows that when a defendant's attorney contributes, defendants win more cases than they lose. Further, when the defendant's attorney does not contribute, defendants lose more cases than they win. While this outcome fits the expected, the effect is relatively small, and Fisher's exact test shows that it is not statistically significant.

Next, I assess the degree to which contributions affect the probability of ruling for the plaintiff in a given case. In Wisconsin in 1998, approximately 53 percent of cases were decided for the plaintiff and 47 percent for the defendant. Thus, with no other information for any given case, the probability of ruling for the defendant is .53 .

I test two models. First, I search for the effect of plaintiff attorney contributions to all justices and defendant attorney contributions to all justices on the probability of a case being decided for the plaintiff. In the second 
Table 1. Plaintiff Attorney Contributions and Success in Court

\begin{tabular}{lcc}
\hline & Plaintiff Wins & Defendant Wins \\
\hline Plaintiff's Attorney Contributes & 14 & 15 \\
Plaintiff's Attorney Does Not Contribute & 25 & 20 \\
$\mathrm{~N}=97$; Fisher's Exact Test: $\mathrm{p}=.635$ & & \\
\hline
\end{tabular}

Table 2. Defendant Attorney Contributions and Success in Court

\begin{tabular}{lcc}
\hline & Plaintiff Wins & Defendant Wins \\
\hline Defendant's Attorney Contributes & 25 & 20 \\
Defendant's Attorney Does Not Contribute & 13 & 10 \\
$\mathrm{~N}=97$; Fisher's Exact Test: $\mathrm{p}=.323$ & & \\
\hline
\end{tabular}

model, I use one independent variable equal to the difference between plaintiff attorney contributions and defendant attorney contributions to predict the probability of a case being decided for the plaintiff. I examine all cases decided by the Wisconsin Supreme Court in its 1998 term with the exception of those for professional discipline. Action in professional discipline cases are brought by a governmental board, thus, there is no variance in the attorney contributions of the plaintiff in those cases. It is best to omit them. This leaves 74 cases. Normally, a dichotomous choice model, such as logit or probit, requires at least 100 cases to asymptotically approach a proper sampling distribution (Long 1997). An alternative for this sample size is a weighted least squares linear probability model which corrects the heteroskedasticity present in OLS estimates of dichotomous variables. I present both logit and linear probability results for this model in Table 3 .

The contribution variables are far from significant in any of the models. Using CLARIFY, a computer program for interpreting statistical results (King, Tomz, and Wittenberg 2000), I generated predicted probabilities across the range of data in the sample. The predicted probability of ruling for the plaintiff never differs significantly from .53 .

The foregoing analyses may suffer from several shortcomings. First, examining the decision of the court as a whole may not be the best place to look for money's influence. After all, donors give to individual justices rather than to members of the full court. While the models presented in Table 3 suggests that money does not change the outcome of a case, we 
Table 3. Modeling the Probability of Ruling for the Plaintiff

\begin{tabular}{lcccc}
\hline & Logit & Linear Prob. & Logit & Linear Prob. \\
\hline Plaintiff Contributions & .665 & .209 & & \\
& 1.221 & .250 & & \\
Defendant Contributions & .374 & .111 & & \\
& .813 & .160 & & \\
Difference in Contributions & & & -.062 & -.025 \\
& & & .625 & .154 \\
Constant & 0.030 & 0.501 & 0.108 & 0.527 \\
Likelihood Ratio / F & 0.255 & 0.065 & 0.233 & 0.059 \\
Pseudo-R / R & 0.570 & 0.600 & 0.010 & 0.030 \\
N = 74. Standard Errors in italics; contributions in thousands of dollars. & & \\
\hline
\end{tabular}

should also test the hypothesis that money can change the vote of an individual justice. Second, the preceding models fail to control for other factors.

\section{Justice-Level Outcomes}

In this section, I model the justices' votes in cases that were not unanimous (common because of institutional norms, see Brace and Hall 1990) or per curiam. After accounting for the non-participation of justices, we are left with 149 observations. The dependent variable is coded 1 if an individual justice votes for the liberal side and 0 if the justice votes conservatively. In the first analysis, I include independent variables for the amount of money the lawyers on the conservative side contributed and the amount that lawyers on the liberal side contributed. In the second analysis, I use a variable equal to the difference between the contributions of the liberal side and the conservative side.

Ideology has been shown to affect judicial decision-making (on the Supreme Court, see Segal and Spaeth 1993; on state supreme courts, see Comparato and McClurg 2002 and Benesh and Martinek 2002). Because attorneys may make contribution decisions on the basis of the ideology of the justices to whom they contribute, I must control for ideology. Accordingly, I include a dummy variable for the justices' previous party affiliation, ${ }^{1}$ coded 1 for Democrats and 0 for Republicans. Party identification has been shown to be a valid measure of ideology on state courts (Pinello 1999). Further, partisan factors have been shown to be significant even in non-partisan elections like Wisconsin's (Hall 2001).

Additionally, I include a dummy variable for whether the state was a party to the case. State attorneys are less likely to contribute, and they are 
often on the conservative side of a case (especially defending questionable search and seizure cases). Further, state attorneys are "repeat players" in the court with an incentive to establish a good reputation, thus they may be more likely to win the case (McGuire 1995).

With a sample of this size, logistic regression is appropriate. Because the error term is likely correlated for decisions by the same justice, I cluster by justice and employ Huber/White robust standard errors. The results are presented in Table 4, and they confirm that ideology exercises a substantial and significant effect on decision making on the Wisconsin State Supreme Court. Further, when the state is a party to a case, the likelihood of a conservative decision (usually the state's side) increases. However, the contribution variables are all far from statistically significant. Even with a conservative one-tailed test, none of the contribution variables would be statistically significant; in fact, for two of the three contribution variables, the standard errors are larger than the coefficients. Once again, it appears that campaign contributions from attorneys have no effect on justices' voting behavior.

\section{A Model of Recusal}

Having found no evidence that money affects judge's votes, I now move to the possibility that hearing a case argued by an attorney who donated to the justice's campaign may lead a justice to recuse him or her self. If judges want to rule in favor of their donors, they will not recuse themselves from cases involving lawyers who contributed. If judges prefer to protect the image of propriety, they will be more likely to recuse themselves in cases when lawyers who are contributors are arguing the case.

Because recusal is a rare event, I employ rare events logistic regression (King and Zeng 2001) with the dependent variable being coded 1 for justices who recuse themselves and 0 otherwise. The independent variable is the sum of the contributions a justice receives from attorneys on either side of a case. The unit of analysis is the individual justice's decision whether or not to recuse himself in each case during the 1998 term. I use all cases considered in 1998 because even in per curiam decisions or cases without dissent, judges may recuse themselves. Because the error term may be correlated across justices, I employ robust standard errors and cluster by justice. The results are presented in Table 5. The coefficients on contributions and the constant are greater than twice their respective standard errors, indicating statistical significance. Using CLARIFY, I generate predicted probabilities for the range of contributions in the sample, with standard errors. I present these in Figure 1. 
Table 4. Logit Models for Individual Justices

\begin{tabular}{lrr}
\hline & Model 1 & Model 2 \\
\hline Liberal Contributions & -.311 & \\
& .655 & \\
Conservative Contributions & -10.702 & \\
& 7.461 & -.104 \\
Difference in Contributions & & .597 \\
& & 1.081 \\
Ideology (Party ID) & .042 & .478 \\
& .491 & .518 \\
State as Party & .440 & .181 \\
& .200 & -.743 \\
Constant & -.647 & .252 \\
& .246 & 17.07 \\
Wald Chi & \\
p $>$ Chi $^{2}$ & 36.76 & 0.007 \\
Note: $\mathrm{N}=149 ;$ Robust Standard Errors in italics; contributions in thousands of dollars. \\
\hline
\end{tabular}

Table 5. Modeling Recusal

\begin{tabular}{lc} 
Total Attorney Contributions & 2.09 \\
& .872 \\
Constant & -4.22 \\
& .319 \\
$\mathrm{~N}$ & 679 \\
Notes: Rare Events Logit Estimates. & \\
& Robust Standard Errors in italics, clustered by judge; contributions in thousands of dollars. \\
\hline
\end{tabular}

For a judge who receives no contributions, the probability of recusal is .01 . However, as you move toward the maximum observed value of $\$ 2,025$, the probability of recusal reaches .51 . While the model seldom predicts recusals above a .5 probability, the significant positive trend does show that justices are sensitive to the sources of their campaign funds. Further, small probabilities are standard for rare events. The results show no support for the campaign contributions for votes hypothesis, that justices will be less likely to recuse themselves when they receive contributions from participating attorneys. 


\section{Figure 1. Predicted Probability of Recusal}

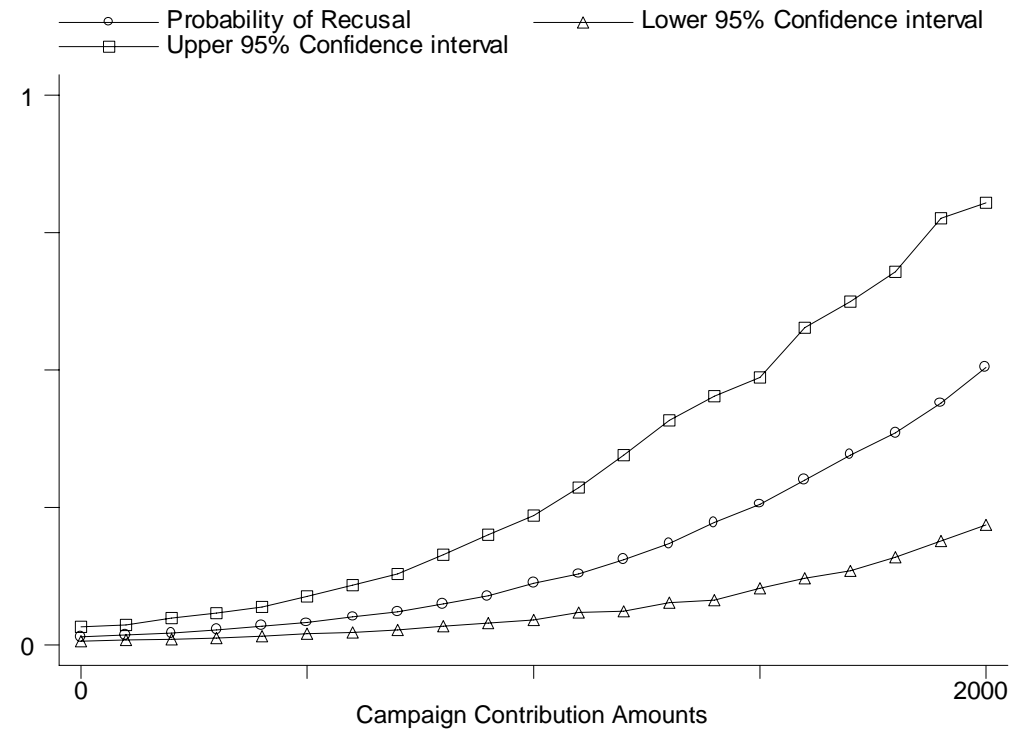

\section{Conclusion}

The foregoing analyses seem to indicate that the prevailing legal system in Wisconsin functions properly. While there always will be anecdotes telling of corrupt judges, as a general rule, lawyers who contribute to judicial campaigns in Wisconsin do not appear to get any special treatment. Moreover, justices of the Wisconsin Supreme Court are more likely to recuse themselves when hearing cases argued by lawyers who contributed to their campaigns.

Why is there no link between campaign contributions and votes? One possible explanation is that contributions are generally not large enough to "buy" favors from the justices involved. The Texas incidents discussed by Champagne $(1986,1988)$ involved contributions of over $\$ 10,000$. If nothing else, the Wisconsin evidence shows that well-tailored campaign finance laws allow candidates to raise enough funds to contest elections without endangering judicial independence.

Another explanation for the lack of correlation comes from political psychology. Gibson (1978) applied psychological role theory to judicial decision-making. He contends that justices may feel constrained to fill a certain role regardless of pressures from the outside. Because of the importance of filling the judicial role as impartial administrator of the law, justices will 
not change their decisions for campaign contributions (or, in combination with the contention in the previous paragraph, they will not abandon their role for the campaign contributions offered to the justices of the Wisconsin State Supreme Court).

This research contributes to the literature on judicial selection. Elections cannot be dismissed as a poor method of judicial selection on the grounds of campaign finance corruption. Further, claims that full public funding is necessary to maintain the integrity of the judiciary are not warranted. The analyses here do not provide any support for the quid pro quo hypothesis of campaign contributions influencing judicial behavior.

\section{NOTES}

${ }^{1}$ Brace, Langer, and Hall (2000) developed an alternative strategy for measuring the ideology of state supreme court justices-Party Adjusted Ideology scores (PAJID). However, I could not locate a PAJID score for Justice N. Patrick Crooks. Replicating the analysis using PAJID scores instead of party identification using for the other six justices makes no difference in the results. The analyses also was re-run with an imputed PAJID score for Justice Crooks, first using his Party ID and second using a combination of Party ID and the PAJID scores of the judges with which he most frequently voted. None of these strategies changed the results of the analysis - the contribution variables are never statistically significant.

\section{REFERENCES}

ABA. 1924. Model Canon of Judicial Ethics. Chicago: American Bar Association.

ABA. 1990. Model Code of Judicial Conduct. Chicago: American Bar Association.

ABA. 1999. Model Code of Judicial Conduct. Chicago: American Bar Association.

ABA Standing Committee on Judicial Independence. 2001. Commission on Public Financing of Judicial Campaigns Report. <http://www.abanet.org/judind/ report072001.pdf>, accessed February 2002.

Banner, Stephen. 1988. Disqualifying Elected Judges from Cases Involving Campaign Contributors. Stanford Law Review 40:449-490.

Benesh, Sarah C., and Wendy Martinek. 2002. State Court Decision Making in Confession Cases. Justice System Journal 23:109-133.

Brace, Paul, and Melinda Gann Hall. 1990. Neo-Institutionalism and Dissent in State Supreme Courts. Journal of Politics 52:54-70.

Brace, Paul, Laura Langer, and Melinda Gann Hall. 2000. Measuring the Preferences of State Supreme Court Judges. Journal of Politics 62:387-413.

California Commission on Campaign Financing. 1995. The Price of Justice: A Los Angeles Area Case Study in Judicial Campaign Financing. Los Angeles: Center for Governmental Studies.

Champagne, Anthony. 1986. The Selection and Retention of Judges in Texas. Southwestern Law Journal 40(May):66-117.

Champagne, Anthony. 1988. Judicial Reform in Texas. Judicature 72:146-161. 
Comparato, Scott A., and Scott McClurg. 2002. State Supreme Court Compliance with Supreme Court Precedent. Paper presented at the Annual meeting of the Midwest Political Science Association, Chicago.

Dubois, Philip. 1986. Penny for Your Thoughts? Campaign Spending in California Trial Court Elections, 1976-1982. Western Political Quarterly 38(June):265-84.

Dunn, Patrick W. 1976. Judicial Selection and the States: A Critical Study with Proposals for Reform. Hofstra Law Review 4:285-304.

Federal Election Commission. 2001. Campaign Finance Law 2000. Washington, DC: Government Printing Office.

Gibson, James. 1978. Judges' Role Orientations, Attitudes, and Decisions: An Interactive Model. American Political Science Review 72:911-924.

Grenzke, Janet. 1989. Shopping in the Congressional Supermarket: The Currency is Complex. American Journal of Political Science 33:1-24.

Hall, Melinda Gann. 2001. State Supreme Courts in American Democracy: Probing the Myths of Judicial Reform. American Political Science Review 95:315-330.

Hall, Melinda Gann. 1992. Electoral Politics and Strategic Voting in State Supreme Courts. Journal of Politics 54:427-446.

Hansen, Mark. 1991. The High Cost of Judging. ABA Journal 77:44.

Jackson, Donald W., and James W. Riddlesperger. 1991. Money and Politics in Judicial Elections: The 1988 Election of the Chief Justice of the Texas Supreme Court. Judicature 74:184-189.

King, Gary, Michael Tomz, and Jason Wittenberg. 2000. Making the Most of Statistical Analyses: Improving Interpretation and Presentation. American Journal of Political Science 44(2):347-361

King, Gary, and Langche Zeng. 2001. Logistic Regression in Rare Events Data. Political Analysis 9(2):137-163.

Long, J. Scott. 1997. Regression Models for Categorical and Limited Dependent Variables. Thousand Oaks, CA: SAGE.

McGuire, Kevin T. 1995. Repeat Payers in the Supreme Court: The Role of Experienced Lawyers in Litigation Success. Journal of Politics 57:187-196.

National Center for State Courts. 1999. How the Public Views the State Courts: A 1999 National Survey. $<$ http://www.ncsc.dni.us/ptc/results/results.pdf $>$, accessed February 2002.

Pallasch, Abdon. 2001. Bar Wants Judges to Clean Up Elections. Chicago Sun-Times, March 15, p. 36.

Pinello, Daniel R. 1999. Linking Party to Judicial Ideology in American Courts: A MetaAnalysis. Justice System Journal 20:219-254.

Schotland, Roy. 1985. Elective Judges' Campaign Financing: Are State Judges' Robes the Emperor's Clothes of American Democracy? Journal of Law and Politics 2:57167.

Segal, Jeffrey, and Harold Spaeth. 1993. The Supreme Court and the Attitudinal Model. Cambridge: Cambridge University Press.

Supreme Court of Texas, State Bar of Texas, and Texas Office of Court Administration. 1999. The Courts and the Legal Profession in Texas-The Insider's Perspective: A Survey of Judges, Court Personnel, and Attorneys. Austin, TX: Texas Office of Court Administration.

Thompson, Joel, and Gary Moncrief. 1998. Campaign Finance in State Legislative Elections. Washington, D.C.: CQ Press.

Ware, Stephen J. 1999. Money, Politics and Judicial Decisions: A Case Study of Arbitration Law in Alabama. Journal of Law and Politics 25(4):645-686. 
Wisconsin Court System Rules. 2002. SCR 60.06, revised January 23, 2002, on-line at $<$ http://www.courts.state.wi.us/html/rules/chap60.htm>, accessed July 2002.

Wisconsin Supreme Court. 1984. Supreme Court Internal Operating Procedures. $<$ http://www.courts.state.wi.us/supreme/sc_iop.asp>, accessed February 2002.

Wright, John R. 1996. Interest groups and Congress: Lobbying, Contributions, and Influence. Boston: Allyn and Bacon. 